Article

\title{
Improved Agricultural Products Drying Through a Novel Double Collector Solar Device
}

\author{
Monica Patricia Camas-Nafate ${ }^{1}$, Peggy Alvarez-Gutiérrez ${ }^{2, *}$,, Edgar Valenzuela-Mondaca ${ }^{3}$ (D), \\ Roger Castillo-Palomera ${ }^{4}$ and Yolanda del Carmen Perez-Luna ${ }^{4}$ \\ 1 Centro Universitario de Tonalá, Universidad de Guadalajara, Av. Nuevo Periférico 555, Ejido San José \\ Tatepozco, Tonalá 45425, Mexico; ie.canaf.monica@gmail.com \\ 2 CONACYT, Tecnológico Nacional de México/Instituto Tecnológico de Tuxtla Gutiérrez, Carretera \\ Panamericana km 1080, Tuxtla Gutiérrez 29050, Mexico \\ 3 Facultad de Ingeniería, Universidad Autónoma de Baja California, Boulevard Benito Juárez y Calle de la \\ Normal s/n, Col. Insurgentes Este, Mexicali 21280, Mexico; evalenzuela.mondaca@uabc.edu.mx \\ 4 Ingeniería en Energía e Ingeniería Agroindustrial, Universidad Politécnica de Chiapas, Carretera \\ Tuxtla-Villaflores km 1 + 500, Las Brisas, Suchiapa 29150, Mexico; \\ roger_castillo_palomera@hotmail.com (R.C.-P.); yperez@upchiapas.edu.mx (Y.d.C.P.-L.) \\ * Correspondence: peggy.alvarez@hotmail.com or pealvarezgu@conacyt.mx; Tel.: +52-961-615-03-80 (ext. 325)
}

Received: 2 April 2019; Accepted: 12 May 2019; Published: 23 May 2019

\begin{abstract}
Backyard agricultural systems are frequently used for food production in rural tropical regions all over the world. The implementation of these systems has been used as a strategy to increase food security, to preserve the phyto and zoo diversity and to provide an alternative income for poorer rural families. Nevertheless, the absence of appropriate preservation mechanisms and nonrenewable energies can lead to significant production losses that could be prevented by the implementation of solar drying devices. The objective of this project was to design, build and validate a double collector solar device for improved drying performance. To evaluate the double collector solar device, four backyard products frequently used in the Mexico Southwest regional diet were used: carrots, chayote squash, tomatoes, and oyster mushrooms. The results showed that the solar device achieved drying efficiencies between 22.8 and $37.9 \%$ by reaching moisture values below the $12.30 \%$ threshold, which according to the international standards is considered as "Low Moisture Food". The evaluation of the double collector solar drier is demonstrated to be an easy-to-apply and environmentally friendly method for food preservation in tropical rural regions by taking advantage of domestic renewable energy resources.
\end{abstract}

Keywords: solar drying; backyard food production; chayote squash; oyster mushroom; tomato; carrot

\section{Introduction}

Tropical countries located in Asia, Africa, and Latin America share climate and demographic conditions with similar food production systems. In these regions, the soil fertility and water abundance favor primary activities such as agriculture and fishing. Therefore, the rural economy is typically organized in family farms which rely on self-consumption and the selling of production surpluses as a source of alternative income [1-5].

Despite the richness and resources abundance, those regions share low Human Development Index (HDI) values. The United Nations Development Programme (UNDP), reports HDI values ranging from 0.5 in Africa to 0.7 in Latin America and Asia. Several reasons for this low development include lack of opportunities, gender and age inequalities particularly in remunerated work, hazardous working conditions and the prevalence of economical non sustainable activities that tend to deplete the resources and to deteriorate the environment [6]. 
In the tropical region of Chiapas, Mexico, a number of initiatives promoted by Governmental and Non Governmental Organizations (NGO) have been implemented to improve quality of life. Those strategies have been oriented to the Millennium Development Goals (MDG), in particular to the following: i. Eradicate extreme poverty and hunger, ii. Promote gender equality and empower women, iii. Reduce child mortality and iv. Ensure environmental sustainability [7].

Nevertheless, the implemented programs have faced different challenges related to the high population dispersion and complicated orography in the region, with the consequent unavailability of electricity, fuel, supplies and insufficient roads and routes to commercialization. Considering the latter, the backyard agriculture systems of mushrooms and vegetables have been recognized as an adequate strategy to increase the levels of food security and to mitigate conflicts between biodiversity conservation and agricultural production [8-11]. In Chiapas, the food production based on backyard agriculture has become an activity with relevant importance. Under these systems, native plants and commercial vegetables included on the basis of the traditional local diet are cultivated, promoting the self-sustainability of the region [12].

From the biologic point of view, the backyard agricultural systems allow the in situ conservation of phyto and zoogenetic resources, as well as the natural selection of germplasm of different plant varieties [13-15]. In economic terms, the backyard agricultural systems contribute to food production, providing energy and protein at low cost. In addition, the production surpluses are an important income source to improve the local economy, which is particularly true for the most vulnerable populations [16]. Unfortunately, the absence of appropriate preservation mechanisms leads to significant losses and it is estimated that in developing countries, nearly $37.26 \%$ of the vegetables produced by small family farms are lost because of a lack of preservation processes [17].

The same scenario is found over tropical regions of the world, where it is very common to have an overproduction of fruits and vegetables in a short harvest period and due to their isolation from the electrical grid and the lack of fossil fuels, traditional preservation methods become unavailable or unaffordable. A renewable and sustainable alternative with the potential to contribute to the MDG by increasing the shelf life and profitability of food products in backyard agricultural systems is the use of solar drying devices. Previous authors have evaluated a number of types of solar equipment in order to increase the shelf life of mushrooms and vegetables. In general, these solar dryers are classified according to the mechanism of airflow, as natural or forced convection driers and into indirect or direct driers if the product receives or not direct solar radiation. Some of the best results in terms of efficiency have been reported with devices that use blowers to induce a flow from the heating plate in the collector to the chamber where the products are dried [18-23]. Also, the drying time has been reduced by the addition of heat storage systems which allow continuing the drying process during the night $[24,25]$. In other cases, some devices were coupled with additional heat sources, such as burners or electric heaters which were powered by photovoltaic or connected to the grid where available [26-28]. Despite the performance of the driers in all these cases being improved, the increase of final cost and their complexity makes them financially unaffordable or sometimes unpractical from the operational and maintenance point of view. For successful solar drier operation in rural environments, the design should be kept as simple and cheap as possible, as well as requiring the minimum investment and maintenance.

Under those conditions, the natural airflow solar devices have become the most attractive alternative. These devices have been successfully tested in the drying of a number of products such as tomato, carrots, medicinal plants, bananas and others [29-32]. Two variations of these devices are used, the indirect and direct driers, depending if the product is receiving direct or indirect solar radiation. According to previous work, the exposure of the products to direct solar radiation produces undesirable changes in the organoleptic properties [24,33], causing rejection from the consumer. On the other hand, the indirect, natural flow solar drying combines the simplicity, low cost, and independent operation from any traditional fuel or source of energy, to produce the best results in terms of color, odor, and taste. 
In this work, a novel natural airflow solar drier was designed; it involves two separate collectors. The first one is a traditional flat-plate greenhouse effect collector, where solar radiation is used to heat the air and a metal plate inside the collection chamber, to produce a natural convection airflow through the drying products. Nevertheless, in these designs the airflow tends to cool down while extracting moisture from the product, causing different drying rates in the chamber, which leads to a decrease in quality in the characteristics of the final product. To prevent this effect, this solar dryer is equipped with a second solar collector coupled to the roof of the device to provide an extra thermal source, which indirectly transfers heat to the drying chamber through a metal plate. By the incorporation of the second solar collector, the loss of thermal energy in the chamber is compensated, homogenizing the drying process and reducing the drying time while avoiding changes in color and flavor due to direct solar radiation exposure.

\section{Materials and Methods}

\subsection{Description fo the Double Collector Solar Dryer}

A double collector solar device was designed and implemented in the city of Tuxtla Gutierrez, Mexico ( $16^{\circ} 44^{\prime} 57.7^{\prime \prime}$ N, 9305'54.9” W) during the days from 29 July to 3 August 2013. This device was built with galvanized steel and has two flat solar collectors (primary and secondary collectors) and a drying cabinet with three drying racks (Figure 1a). The air enters at the bottom of the first collector through a metallic grid to avoid contamination, and flows towards the drying chamber and second solar collector through the airflow channel until it reaches the chimney (Figure 1b).

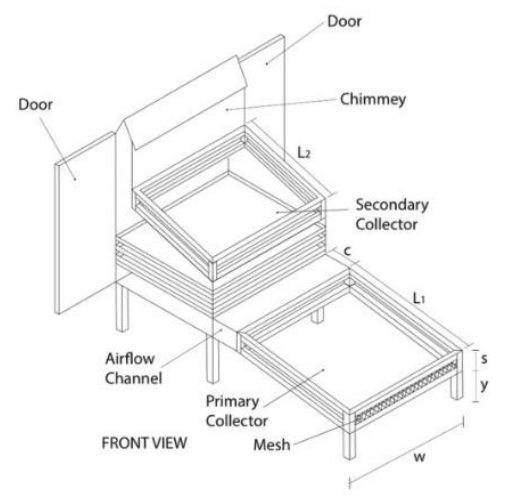

(a)

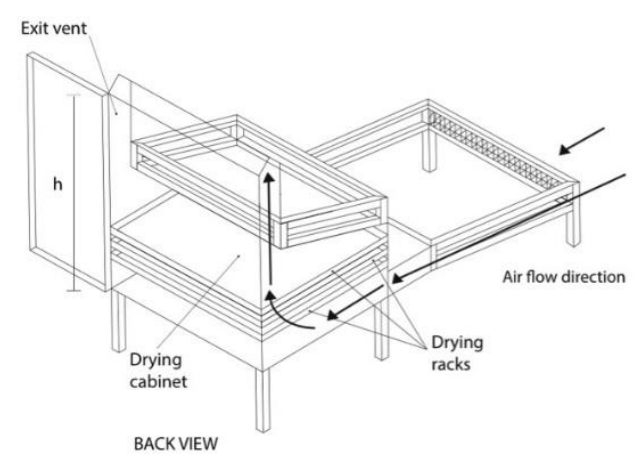

(b)

Figure 1. Schematic views of the double collector solar device. (a) Front view; (b) Back view.

The primary collector is a single pass air-heater with a top glass cover of $1 \mathrm{~cm}$ thick and it is located on the lower part of the device. The dimensions of this first collector are $1 \times 1 \mathrm{~m}(\mathrm{~L} 1 \times \mathrm{w})$ and the inclination angle is 16 degrees according to the latitude of the zone (Figure 2a). The collector is coupled with the drying chamber through an air channel of $23 \mathrm{~cm}$ wide (c) and $15 \mathrm{~cm}$ high (s) (Figure 2a). The drying cabinet has a rectangular shape and houses three drying racks with a calculated capacity of $7 \mathrm{~kg}$, but for the evaluation, only $3 \mathrm{~kg}$ of wet product were used. The dimensions of the cabinet are $122 \mathrm{~cm}$ high (h), $100 \mathrm{~cm}$ long (L) and $70 \mathrm{~cm}$ wide (w). The drying racks are made with 304 stainless steel mesh (\#6 mesh, with $3 \mathrm{~mm}$ aperture and $1.2 \mathrm{~mm}$ wire diameter) and are stacked inside the drying chamber separated $10 \mathrm{~cm}$ from each other, their dimensions are $96 \mathrm{~cm}$ long and $66 \mathrm{~cm}$ wide (Figure 2b). According to this disposition, the heated air coming from the first solar collector passes through the first rack exchanging heat and removing water from the drying products. As the process continues in superior racks, the drying effect is reduced due to the increase of moisture and cooling of the airflow, leading to undesirable differences in water content and appearance in the final product. In order to prevent the temperature in the drying chamber from dropping, the roof of the drying chamber was designed as a second greenhouse effect heat collector with the same angle and 
characteristics of the first one, but to avoid the disadvantages of the direct solar exposure of the drying products, the solar energy gained by the second collector is used to heat a metal plate that acts as the roof of the drying chamber, transferring heat indirectly to the drying products. In this way, this design is intended to take advantage of any additional heat gain to keep the air temperature inside the drying chamber as high and homogeneous as possible, but avoiding the undesirable effects of the solar direct exposure of the drying products. The temperature in each rack was monitored via three temperature sensors TS18B20 (1.5\% maximum error) coupled to an Arduino card (Figure 2c).

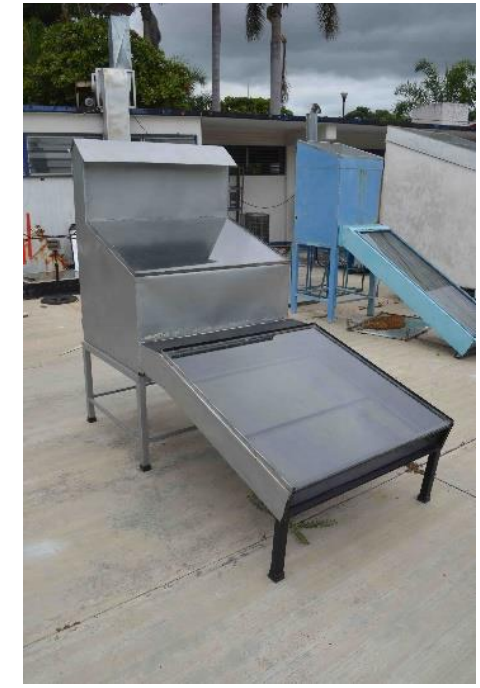

a

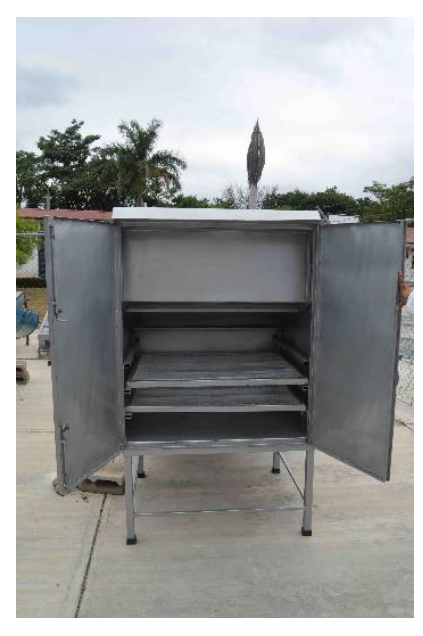

b

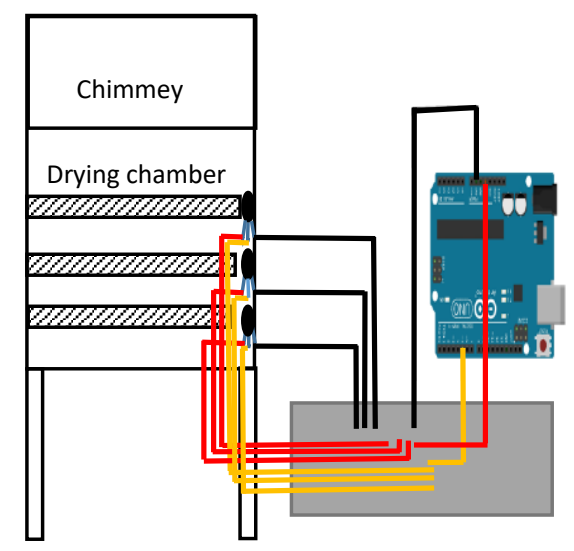

c

Figure 2. Double collector solar device. (a) Lateral view; (b) Drying chamber; (c) Schematic diagram of temperature sensors TS18B20 connected to the Arduino platform in the double collector solar drier.

\subsection{Crop Characteristics}

In this project, four agricultural products were selected due their frequent utilization in the local diet: carrot (Daucus carota), chayote squash (Scheium edule), tomato (Solanum lycopersicum) and oyster mushroom (Pleurotus ostreatus). The maturity stage selected was determined according with the scale applicable to each product, using Red stage for tomatoes [34], Light Green, Thin-Skinned Pear-Shaped for Chayote squash [35], Long Orange for Carrot [36] and Fully Developed Basidiocarp for Oyster mushroom [37]. The products were cut in three different shapes in order to determine the relationship between their size and geometry and the drying kinetics. The cuts analyzed were shredded $(10 \mathrm{~mm}$ thick $\times 10 \mathrm{~mm}$ width by $50 \mathrm{~mm}$ long), chopped (cubes of $10 \mathrm{~mm}$ by side) and sliced (10 $\mathrm{mm}$ thick). Oyster mushroom was dried only in sliced cut due to the morphological characteristics of the product. The drying process was performed for each product separately. Before the evaluation, all products were visually inspected to ensure uniform maturity and color and the different cuts were carefully disposed over the trays to prevent overlapping, forming a single-layer of fresh product. All the procedures were performed in agreement with Codex Alimentarius CRC/RCP 5-1971 [38]. The initial and final moisture was determined by taking a $10 \mathrm{~g}$ sample for each evaluation, in a thermobalance (Ohaus ${ }^{\circledR}$ MB45 moisture analyzer) according to the standard NMX-F-428-1982 [39]. Also the percentage of water was calculated during the drying process by assessing the water loss in three different $40 \mathrm{~g}$ samples every 80 min until a moisture content of $12 \%$ or less was determined, to accomplish the "Low Moisture Food" definition in accordance with the CODEX STAN CAC/RCP 75-2015 [40] code applicable to dried fruits and vegetables and to the CODEX STAN 39-1981 [41] for dried edible fungi. The drying evaluation was carried out during March of 2013. The outside temperature was recorded with a humidity and temperature sensor DHT11 (Keyes) coupled with an Arduino card and the insolation determined with 
a Vaisala Pyranometer model QMS101 (Hukseflux ${ }^{\circledR}$ ) in order to validate the results. All measurements were performed in triplicate.

\subsection{Drying Curves}

The moisture ratio (MR) was calculated according Equation (1) [42]

$$
M R=\frac{M-M_{e}}{M_{0}-M_{e}}
$$

where, $M$, is the moisture content wet basis at time $(t), M_{e}(\mathrm{~g})$, is the equilibrium moisture content, $M_{0}(\mathrm{~g})$ is the initial moisture content.

The moisture content wet basis was calculated according [43]

$$
M=\frac{w_{(t)}-d}{w_{0}} * 100 \%
$$

where, $w_{(t)}$, is the mass of the wet material at instant $t, d$, is the mass of dry materials and $w_{0}$, is the initial mass.

Whereas, the equilibrium moisture was calculated according to [44].

$$
M_{e}=\frac{1800}{s}\left[\frac{K U_{r}}{1-K U_{r}}+\left(\frac{K_{e q 1} K U_{r}+2 K_{e q 1} K_{e q 2} K^{2} U_{r}^{2}}{1+K_{e q 1} K U_{r}+K_{e q 1} K_{e q 2} K^{2} U_{r}^{2}}\right)\right]
$$

where, $U_{r}$, is the relative humidity, and, $s, K, K_{e q 1}, K_{e q 2}$ are coefficients calculated according to Equations (4)-(7)

$$
\begin{gathered}
s=330+0.452 T_{b s}+0.00415 T_{b s}^{2} \\
K=0.791+0.000463 T_{b s}-0.0000000844 T_{b s}^{2} \\
K_{e q 1}=6.34+0.000775 T_{b s}-0.0000935 T_{b s}^{2} \\
K_{e q 2}=1.09+0.0284 T_{b s}-0.0000904 T_{b s}^{2}
\end{gathered}
$$

where $T_{b s}$ is the dry bulb temperature calculated by psychrometric tables from the temperature inside the device cabinet.

\subsection{Drying Efficiency}

The collecting area and the insolation were used to calculate the available energy to perform the drying process in the solar device. This parameter, together with the water loss and the latent heat of evaporation of water, were used to determine the drying efficiency, $\eta_{d}$ Equation (8). This value differentiates from the thermal efficiency, because in the first case, not only is the capacity of the dryer to increase the air temperature assessed but also the capacity to effectively remove water from the products, providing more relevant information about the device performance.

$$
\eta_{d}=\frac{M_{w} L_{t}}{I_{t} A_{T} t}
$$

where, $\eta_{d}$, is the drying efficiency, $\mathrm{M}_{\mathrm{W}}(\mathrm{kg})$ is the mass of water lost, $\mathrm{L}_{\mathrm{t}}\left(\frac{\mathrm{MJ}}{\mathrm{kg}}\right)$ is the latent heat of evaporation of water, $\mathrm{I}_{t}\left(\frac{\mathrm{W}}{\mathrm{m}^{2}}\right)$ the incident solar radiation; $\mathrm{A}_{\mathrm{T}}\left(\mathrm{m}^{2}\right)$ is the total exposed area for both collectors, $t$ the time in seconds that it took the solar device to accomplish the drying process and $\eta_{d}$ is the drying efficiency $(\%)$. 


\subsection{Drying Rate}

The drying rate, $N\left(\frac{\mathrm{g} \text { water }}{\mathrm{g} \text { dry matter }}\right)$ was determined according to Equation (9), where the water mass removed per unit of time was calculated for each assessed product.

$$
N=\frac{-W_{d} \Delta M_{d b}}{A_{s} t}
$$

where, $-W_{d}$ is the dry product weight $(\mathrm{kg}), \Delta M_{d b}$, is the moisture reduction (\%), $A_{s}$, the drying area $\left(\mathrm{m}^{2}\right)$ and $\Delta t$ is the drying time (s).

\section{Results and Discussion}

\subsection{Drying Conditions}

The drying process of carrots, chayote squash, tomato, and oyster mushrooms was performed independently in triplicate in three different cuts. The measured drying conditions are shown in Table 1.

Table 1. Drying conditions and results.

\begin{tabular}{ccccc}
\hline Parameter & Carrot & Chayote Squash & Tomato & Oyster Mushroom \\
\hline Mean ambient temperature $\left({ }^{\circ} \mathrm{C}\right)$ & 26 & 29.8 & 30.25 & 33.48 \\
Ambient relative humidity $(\%)$ & 79.75 & 74.9 & 68.5 & 74.82 \\
Average insolation $\left(\mathrm{W} / \mathrm{m}^{2}\right)$ & 565.0 & 641.1 & 723.48 & 600.14 \\
Drying time $(\mathrm{h})$ & 5.33 & 8 & 6.66 & 5.33 \\
Average product temperature $\left({ }^{\circ} \mathrm{C}\right)$ & 32 & 37.35 & 41.43 & 34.62 \\
Initial moisture content $(\%)$ & 81 & 93 & 93 & 89 \\
Final moisture content $(\%)$ & 12.26 & 12.30 & 12.04 & 9.58 \\
Average drying kinetics $(\mathrm{kg} \mathrm{w} / \mathrm{kg}$ dry s) & 0.0109 & 0.0097 & 0.0197 & 0.0177 \\
Drying efficiency $\left(\eta_{d}\right)(\%)$ & 37.9 & & 22.8 & 36.3 \\
\hline
\end{tabular}

The initial water content of all the four evaluated products ranged between $81 \%-93 \%$ and all products were dried in the double collector solar device until the water content was measured between 9.58 and $12.30 \%$ wt. These values are considered "Dehydrated" by the CAC/RCP 75-2015 [40] and the CODEX STAN 39-1981 [41].

From Table 1, a relation between the drying time and the initial moisture content was observed. Since the best efficiency was obtained for carrots, $37.90 \%$, which had also the lowest initial moisture content $(81 \%)$, followed by mushrooms with an initial $89 \%$ of water and a drying efficiency of $36.30 \%$, then tomato and chayote, both with $93 \%$ of water but different drying efficiencies, $25.90 \%$ for tomato and $22.80 \%$ for chayote. This difference is attributed to the mucilaginous nature of the chayote's sap [45], which decreases the free water content and reduces the water removing process. The latter can be validated by analyzing the drying efficiency behavior also shown in Table 1 . According to these values, the products with highest initial water content showed a higher drying efficiency (tomato and mushrooms) with the exception of chayote, that had high initial moisture but the lowest drying kinetics because of the aforementioned reason.

Figure 3 shows the measured air temperatures at the inlet and in the three racks of the drying chamber, placed in the chamber as described in materials and methods. As expected, the highest temperatures were reached at the bottom rack because the effect of the first solar collector. After losing temperature, the air continues ascending to the chimney and diminishing its drying capacity, nevertheless, thanks to the second collector contribution, the temperatures in the upper and middle racks are kept very similar, maintaining the homogeneity of the process and the quality of the final product. 


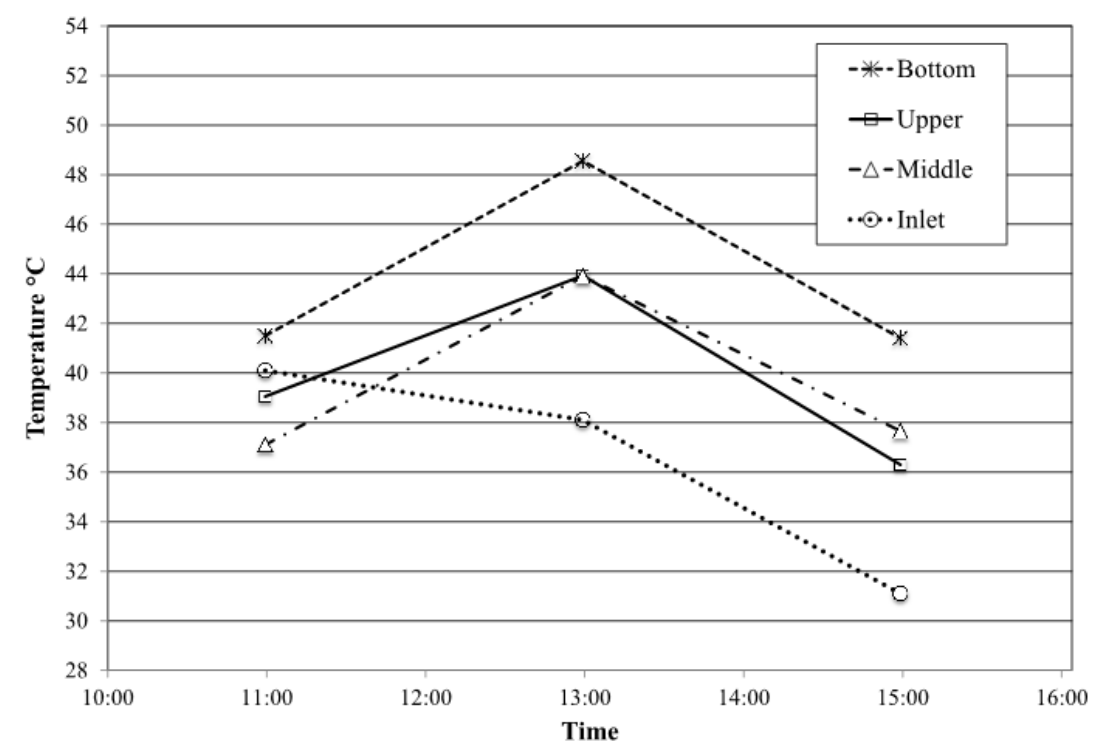

Figure 3. Temperature profiles when entering the device and during its flow through the drying chamber.

\subsection{Drying Curves}

Figure 4 shows the drying curves for four products in the solar drier. The experiment was carried out per batch of one product; the moisture ratio corresponds to the total mass loss of all types of cuts until the equilibrium moisture is reached. Tmin corresponds to the lower temperature registered by any of the three sensors. Tmax corresponds to the highest temperature record by any of the three sensors. Tavg corresponds to the average of the temperature recorded by all three sensors during the process; this temperature was used to calculate the data plotted in the drying curves (Table 2). Each plot represents the moisture lost during the drying time, from the initial fresh product, until reaching the equilibrium moisture in order to analyze the water loss differences for each product.

Table 2. Temperature in the drying cabinet for the drying curves determination (Figure 4).

\begin{tabular}{cccc}
\hline Product & $\mathbf{T}_{\min }\left({ }^{\circ} \mathbf{C}\right)$ & $\mathbf{T}_{\max }\left({ }^{\circ} \mathbf{C}\right)$ & $\mathbf{T}_{\text {avg }}\left({ }^{\circ} \mathbf{C}\right)$ \\
\hline Carrot & 29 & 41.5 & 32 \\
Chayote squash & 29.7 & 45.8 & 37 \\
Tomato & 34 & 45 & 41 \\
Oyster mushroom & 24.1 & 48.1 & 33.9 \\
\hline
\end{tabular}




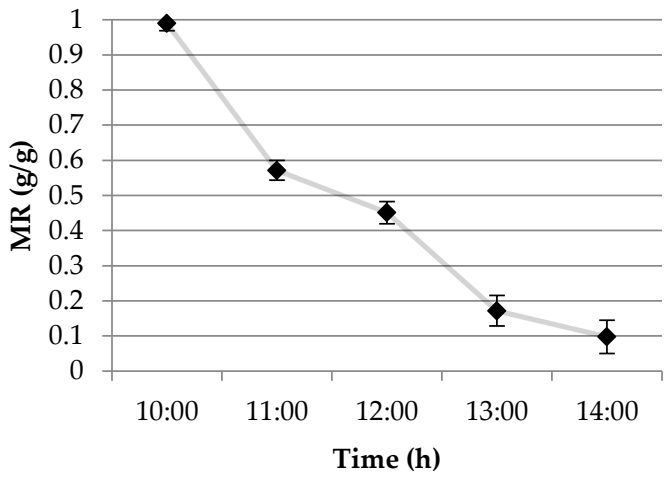

(a)

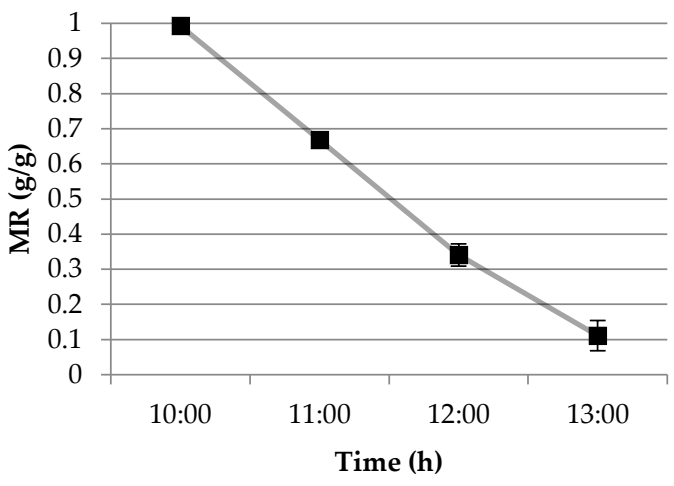

(c)

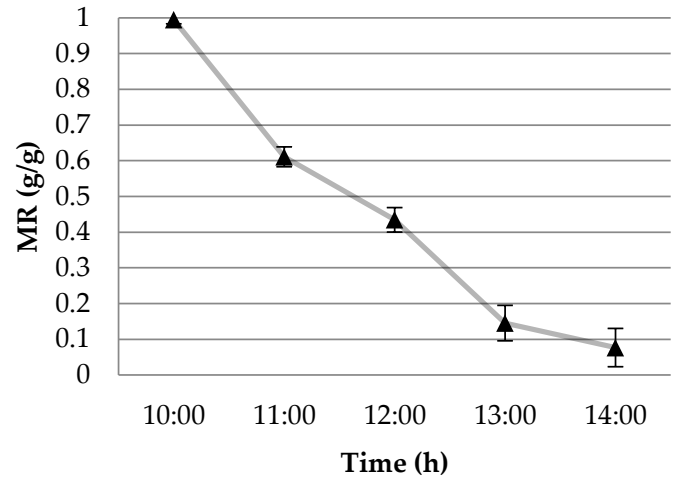

(b)

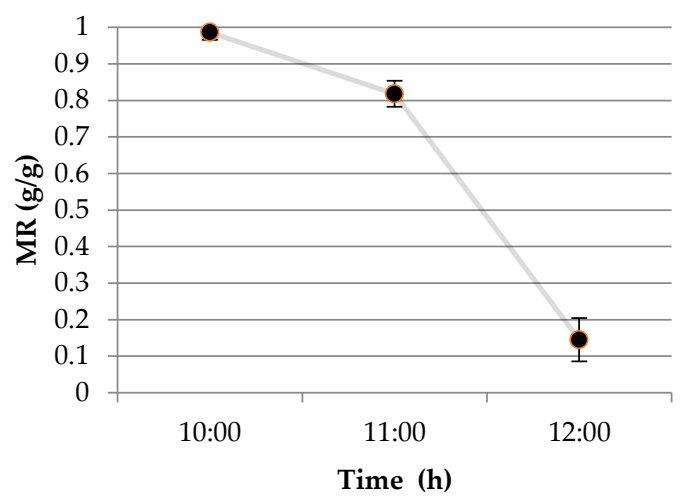

(d)

Figure 4. Drying curves. (a) Carrot; (b) Chayote squash; (c) Tomato and (d) Oyster mushroom.

The drying curves (Figure 4) show that carrots, chayote and tomatoes lose between 30\% and 40\% of their moisture during the first hour of drying, while oyster mushroom only loses $20 \%$ during the same time. However, oyster mushroom reached equilibrium moisture faster $(2 \mathrm{~h}$, compared with 3 and $4 \mathrm{~h}$ for the rest of the products). Considering that chayote and tomatoes were dried under slightly higher temperatures (from Table 2, average drying temperatures of 37 and $41^{\circ} \mathrm{C}$ respectively), this indicated that the drying time is a relation between the drying temperature and the nature of the product.

\subsection{Drying Efficiency}

Figure 5 shows the drying kinetics for all the four products and the 3 different cuts evaluated in the solar drier. According to Figure 5, the drying kinetics decrease exponentially with respect to the moisture content. This behavior is typical for vegetables in any dryer and is related to an initial accelerated moisture decrease related to the "Free Water" content [46]. During this stage, most of the moisture removed is water with a high vapor pressure due to the weak bonding to the dry base product. The rapid initial drying rate is followed by a much slower water-removing stage, starting around the $160 \mathrm{~min}$ for mushrooms and at $240 \mathrm{~min}$ for the other products, until the end of the drying process.

Figure 5 also shows that there is not a concluding relation between the shape and the drying rate. From the products and cuts evaluated, carrots were dried slightly better when prepared in slices, while tomato and chayote dried practically at the same time independently of the cut. This behavior seems to contradict previous results where preparation cuts with the increased area improved the drying process with tomatoes [47], and for chayote squash [48]. Nevertheless, in this case, the effect of the double solar collector helps to homogenize the temperature in the drying chamber. Figure 3 shows the measured air temperatures at the inlet and in the three racks of the drying chamber, placed in the bottom, middle 
and top part of the chamber. As expected, the highest temperatures were reached at the bottom rack because the effect of the first solar collector. After losing temperature, the air continues ascending to the chimney and diminishing its drying capacity, nevertheless, thanks to the second collector contribution, the temperatures in the upper and middle racks are kept very similar, maintaining the homogeneity of the process. As a result, the drying process is not only dependent on the airflow in contact with the exposed surface related to the product shape, but also on the air temperature increased by the additional contribution of the second collector.

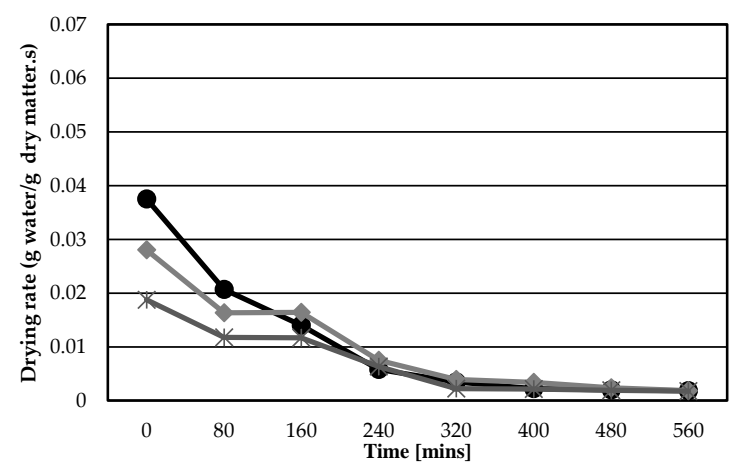

a

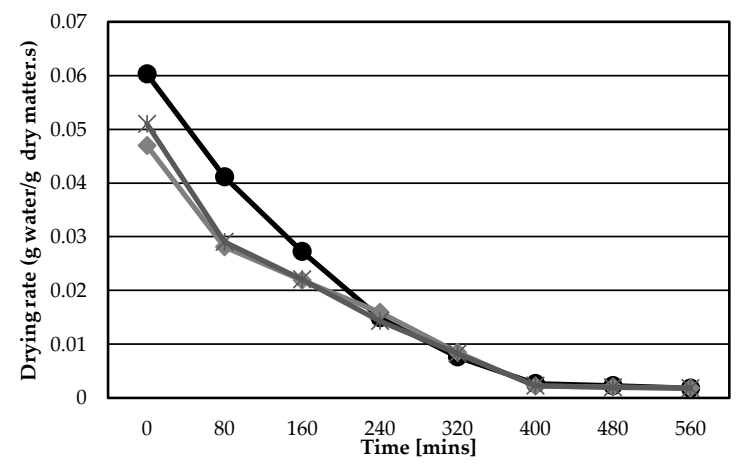

c

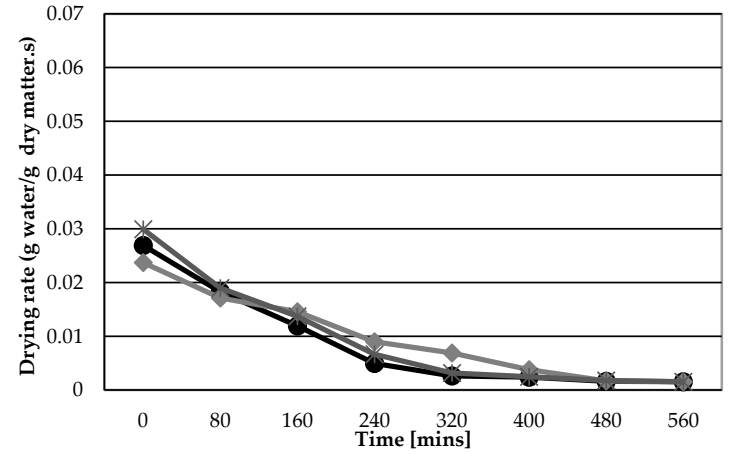

b

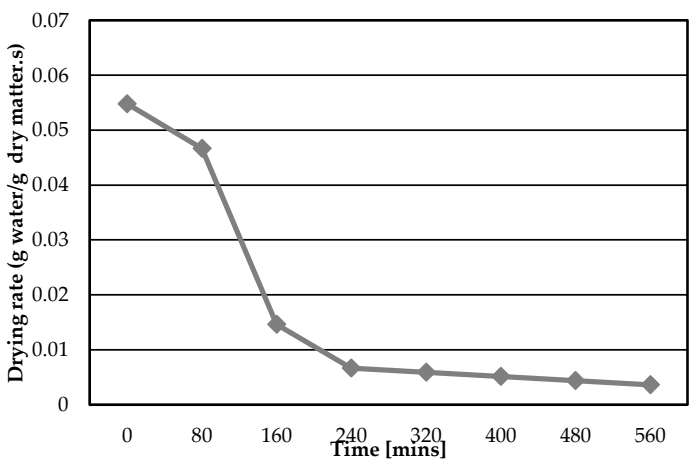

d

Figure 5. Variation of drying rate with drying time: (a) Carrots; (b) Chayote squash; (c) Tomato and (d) Oyster mushroom. For (a)-(c) shredded (solid circles), chopped (rhombuses), slices (asterisks).

\subsection{Dried Products}

Figure 6 shows the drying results for all four products. Despite the changes in appearance due the lost of moisture, all the products kept their characteristic color, odor, and flavor. Also, the drying temperature during the process was found to be in the optimum range where the organoleptic properties as well as the bioactive compounds such as lycopene, beta-carotene, starch, dietary fiber and antioxidants of the dried products are preserved and in some cases enhanced [49]. 


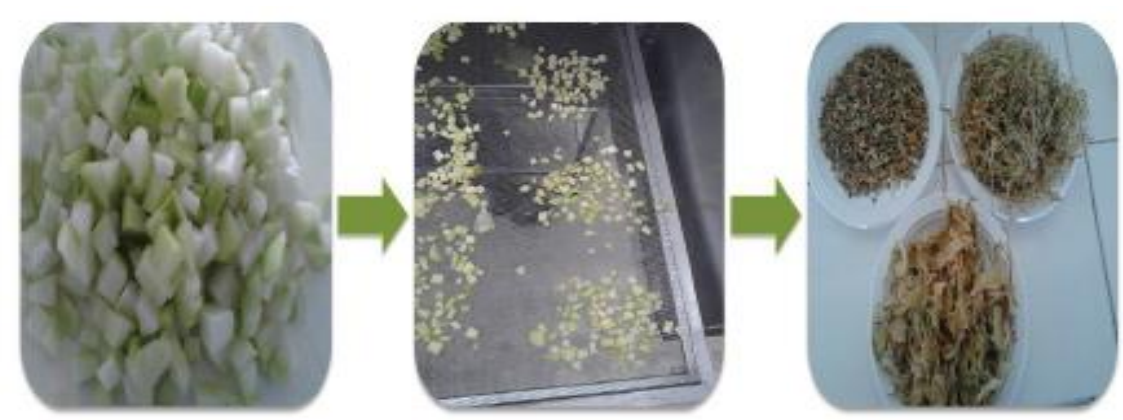

(a)
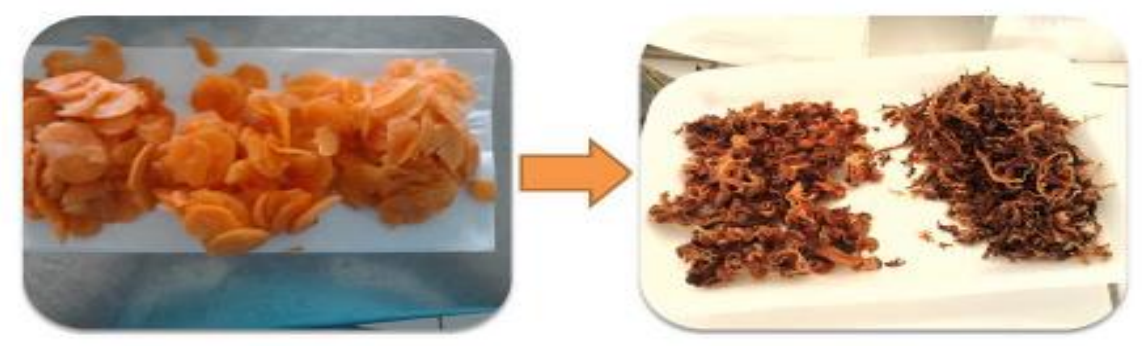

(b)
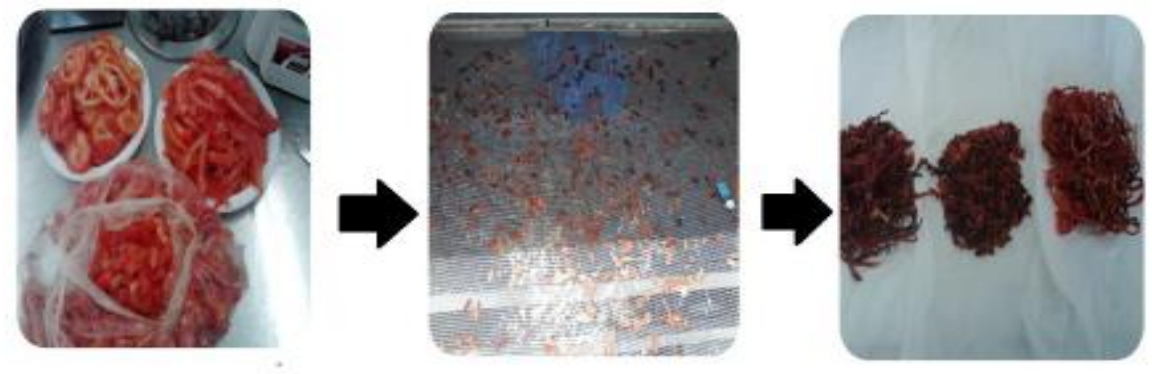

(c)
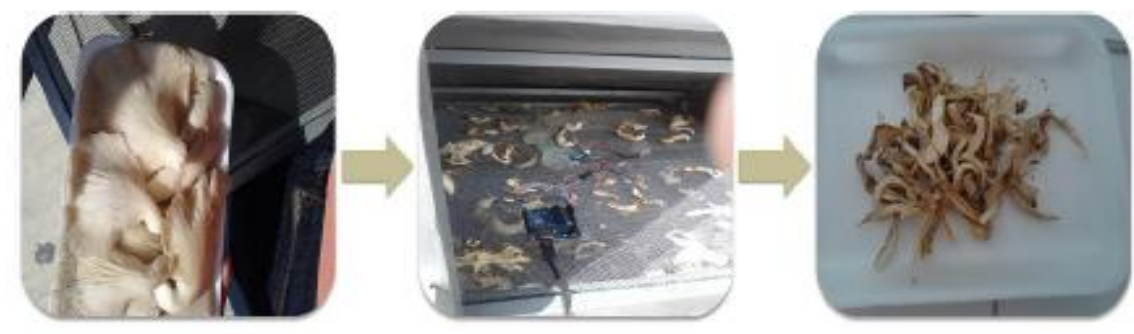

(d)

Figure 6. Drying products in double collector solar device: (a) Chayote squash; (b) Carrot; (c) Tomato; (d) Oyster mushroom. From fresh (left) to dry (right).

\section{Conclusions}

Drying is an ancient technique that has been used to preserve agricultural products. Solar drying in particular involves a number of challenges because of the variations in the drying conditions and to the changes in the cellular structure and the organoleptic properties during the process, causing rejection by the consumer. The incorporation of a second solar collector in the evaluated device was demonstrated to be an appropriate strategy to improve the drying process, keeping the system simple and inexpensive without the need of nonrenewable energies.

The obtained results proved that the solar drying can be an economic, low energy consumption and environmentally friendly alternative for rural communities to help reduce the postharvest losses of backyard products. The use of this food system not only helps to provide a source of alternative 
income for low income families but also can increase the consumption availability of the products, improving food security and favoring biodiversity conservation.

Author Contributions: Conceptualization, P.E.A.-G. and M.P.C.-N.; methodology, M.P.C.-N. and P.E.A.-G. and R.C.-P.; validation, Y.d.C.P.-L. and P.E.A.-G.; formal analysis, M.P.C.-N., P.E.A.-G. and E.V.-M.; investigation, M.P.C.-N. and P.E.A.-G.; resources, P.E.A.-G. and R.C.-P.; data curation, M.P.C.-N., P.E.A.-G. and E.V.-M.; writing-original draft preparation, P.E.A.-G. and E.V.-M.; writing-review and editing, E.V.-M. and P.E.A.-G.; visualization, P.E.A.-G. and E.V.-M.; supervision, P.E.A.-G.; project administration, P.E.A.-G.

Funding: This research was funded by the "Programa de Mejoramiento del Profesorado de la Secretaría de Educación Pública de México" (Project number: PROMEP UPCHIS-PTC-011).

Conflicts of Interest: The authors declare no conflict of interest.

\section{References}

1. Eriksson, H.; Adhuri, D.S.; Adrianto, L.; Andrew, N.L.; Apriliani, T.; Daw, T.; Evans, L.; Garces, L.; Kamanyi, E.; Mwaipopo, R.; et al. An ecosystem approach to small-scale fisheries through participatory diagnosis in four tropical countries. Glob. Environ. Chang. 2016, 36, 56-66. [CrossRef]

2. FAO. The Future of Food and Agriculture-Trends and Challenges; Food and Agriculture Organization: Rome, Italy, 2017; ISBN 9789251095515.

3. Graeub, B.E.; Chappell, M.J.; Wittman, H.; Ledermann, S.; Kerr, R.B.; Gemmill-Herren, B. The State of Family Farms in the World. World Dev. 2016, 87, 1-15. [CrossRef]

4. Pennington, J.T.; Mahoney, K.L.; Kuwahara, V.S.; Kolber, D.D.; Calienes, R.; Chavez, F.P. Primary production in the eastern tropical Pacific: A review. Prog. Oceanogr. 2006, 69, 285-317. [CrossRef]

5. Renwick, A.R.; Vickery, J.A.; Potts, S.G.; Bolwig, S.; Nalwanga, D.; Pomeroy, D.E.; Mushabe, D.; Atkinson, P.W. Achieving production and conservation simultaneously in tropical agricultural landscapes. Agric. Ecosyst. Environ. 2014, 192, 130-134. [CrossRef]

6. United Nations United Nations Millennium Development Goals. Available online: http://www.un.org/ millenniumgoals/ (accessed on 19 May 2019).

7. FAO. Global Agriculture Towards 2050. In Proceedings of the High Level Expert Forum-How to Feed World 2050, Rome, Italy, 12-13 October 2009; pp. 1-4.

8. Albores Pérez, B.; Álvarez Gutiérrez, P.E. Chain value analysis of production of mushroom species (Pleurotus spp.) In four populations of Chiapas. Acta Univ. 2015, 25, 51-58. [CrossRef]

9. Arias-Reyes, L.M. El Huerto Familiar o Solar Maya-Yucateco Actual; Secretaría de Recursos Naturales y Protección Ambiental del Estado de Tabasco: Villahermosa, México, 2012; p. 544, ISBN 9786077637684.

10. Chávez-García, E.; Rist, S.; Galmiche-Tejeda, Á. Lógica de manejo del huerto familiar en el contexto del impacto modernizador en Tabasco, México. Cuadernos Desarrollo Rural 2012, 9, 177-200.

11. Kirschenmann, F. Alternative agriculture in an energy- and resource-depleting future. Renew. Agric. Food Syst. 2010, 25, 85-89. [CrossRef]

12. Martínez-Rodríguez, J.C.; García-Chong, N.R.; Trujillo-Olivera, L.E.; Noriero-Escalante, L. Inseguridad alimentaria y vulnerabilidad social en Chiapas: El rostro de la pobreza. Nutr. Hosp. 2015, 31, 475-481.

13. Bvenura, C.; Afolayan, A.J. The role of wild vegetables in household food security in South Africa: A review. Food Res. Int. 2015, 76, 1001-1011. [CrossRef]

14. Damon, A.; Soriano, M.P.; Rivera del Lourdes, M.; Rivera, M.D. Substrates and fertilization for the rustic cultivation of in vitro propagated native orchids in Soconusco, Chiapas. Renew. Agric. Food Syst. 2005, 20, 214-222. [CrossRef]

15. Goland, C.; Bauer, S. When the apple falls close to the tree: Local food systems and the preservation of diversity. Renew. Agric. Food Syst. 2004, 19, 228-236. [CrossRef]

16. Pretty, J.N.; Morison, J.I.L.; Hine, R.E. Reducing food poverty by increasing agricultural sustainability in developing countries. Agric. Ecosyst. Environ. 2003, 95, 217-234. [CrossRef]

17. FAO. Pérdidas y Desperdicios de Alimentos en América Latina y el Caribe; Food and Agriculture Organization: Rome, Italy, 2015; pp. 1-44.

18. Castillo-Téllez, M.; Pilatowsky-Figueroa, I.; López-Vidal, E.C.; Sarracino-Martínez, O.; Hernández-Galvez, G. Dehydration of the red chilli (Capsicum annuum L., costeño) using an indirect-type forced convection solar dryer. Appl. Therm. Eng. 2017, 114, 1137-1144. [CrossRef] 
19. Gatea, A.A. Performance evaluation of a mixed-mode solar dryer for evaporating moisture in beans. J. Agric. Biotechnol. Sustain. Dev. 2011, 3, 65-71.

20. Hegde, V.N.; Hosur, V.S.; Rathod, S.K.; Harsoor, P.A.; Narayana, K.B. Design, fabrication and performance evaluation of solar dryer for banana. Energy. Sustain. Soc. 2015, 5, 23. [CrossRef]

21. Mghazli, S.; Ouhammou, M.; Hidar, N.; Lahnine, L.; Idlimam, A.; Mahrouz, M. Drying characteristics and kinetics solar drying of Moroccan rosemary leaves. Renew. Energy 2017, 108, 303-310. [CrossRef]

22. Mustayen, A.G.M.B.; Rahman, M.M.; Mekhilef, S.; Saidur, R. Performance evaluation of a solar powered air dryer for white oyster mushroom drying. Int. J. Green Energy 2015, 12, 1113-1121. [CrossRef]

23. Yahya, M.; Fudholi, A.; Hafizh, H.; Sopian, K. Comparison of solar dryer and solar-assisted heat pump dryer for cassava. Sol. Energy 2016, 136, 606-613. [CrossRef]

24. Baniasadi, E.; Ranjbar, S.; Boostanipour, O. Experimental investigation of the performance of a mixed-mode solar dryer with thermal energy storage. Renew. Energy 2017, 112, 143-150. [CrossRef]

25. Qiu, Y.; Li, M.; Hassanien, R.; Wang, Y.; Luo, X.; Yu, Q. Performance and operation mode analysis of a heat recovery and thermal storage solar-assisted heat pump drying system. Sol. Energy 2016, 137, 225-235. [CrossRef]

26. Madhlopa, A.; Ngwalo, G. Solar dryer with thermal storage and biomass-backup heater. Sol. Energy 2007, 81, 449-462. [CrossRef]

27. Prasad, J.; Vijay, V.K. Experimental studies on drying of Zingiber officinale, Curcuma longa 1. and Tinospora cordifolia in solar-biomass hybrid drier. Renew. Energy 2005, 30, 2097-2109. [CrossRef]

28. Reyes, A.; Mahn, A.; Cubillos, F.; Huenulaf, P. Mushroom dehydration in a hybrid-solar dryer. Energy Convers. Manag. 2013, 70, 31-39. [CrossRef]

29. Azaizia, Z.; Kooli, S.; Elkhadraoui, A.; Hamdi, I.; Guizani, A.A. Investigation of a new solar greenhouse drying system for peppers. Int. J. Hydrogen Energy 2017, 42, 8818-8826. [CrossRef]

30. Fadhel, A.; Kooli, S.; Farhat, A.; Bellghith, A. Study of the solar drying of grapes by three different processes. Desalination 2005, 185, 535-541. [CrossRef]

31. Lingayat, A.; Chandramohan, V.P.; Raju, V.R.K. Design, Development and Performance of Indirect Type Solar Dryer for Banana Drying. Energy Procedia 2017, 109, 409-416. [CrossRef]

32. Sallam, Y.I.; Aly, M.H.; Nassar, A.F.; Mohamed, E.A. Solar drying of whole mint plant under natural and forced convection. J. Adv. Res. 2015, 6, 171-178. [CrossRef]

33. Hossain, M.A.; Woods, J.L.; Bala, B.K. Optimisation of solar tunnel drier for drying of chilli without color loss. Renew. Energy 2005, 30, 729-742. [CrossRef]

34. Huang, Y.; Lu, R.; Chen, K. Prediction of firmness parameters of tomatoes by portable visible and near-infrared spectroscopy. J. Food Eng. 2018, 222, 185-198. [CrossRef]

35. Nummer, B.A. National Centre for Home Food Preservation. Available online: https://nchfp.uga.edu/ publications/nchfp/factsheets/chayote.html (accessed on 9 May 2019).

36. Alasalvar, C.; Grigor, J.M.; Zhang, D.; Quantick, P.C.; Shahidi, F. Comparison of volatiles, phenolics, sugars, antioxidant vitamins, and sensory quality of different colored carrot varieties. J. Agric. Food Chem. 2001, 41, 1410-1416. [CrossRef]

37. Girmay, Z.; Gorems, W.; Birhanu, G.; Zewdie, S. Growth and yield performance of Pleurotus ostreatus (Jacq. Fr.) Kumm (oyster mushroom) on different substrates. AMB Express 2016, 6, 87. [CrossRef]

38. FAO. Codex Alimentaius: Code of Hygienic Practice for Dehydrated Fruits and Vegetables including Edible Fungi (CAC/RCP5-1971). Available online: http://www.fao.org/fao-who-codexalimentarius/codex-texts/ codes-of-practice/en/ (accessed on 9 May 2019).

39. Normas Mexicanas. NMX-F-428-1982. Determination of Moisture (Thermobalance Rapid Method); DGN: Naucalpan, Mexico, 1982.

40. FAO. Codex Alimentaius: Code of Hygienic Practice for Low-Moisture Foods. (CAC/RCP 75-2015). Available online: http://www.fao.org/fao-who-codexalimentarius/codex-texts/codes-of-practice/en/ (accessed on 9 May 2019).

41. FAO. Codex Alimentaius: Codex Standard for Dried Edible Fungi Codex Stan 1939-1981. Available online: http://www.fao.org/fao-who-codexalimentarius/sh-proxy/es/?lnk=1\&url=https\%253A \%252F\% 252Fworkspace.fao.org\%252Fsites\%252Fcodex\%252FStandards\%252FCODEX\%2BSTAN\%2B39-1981\% 252FCXS_039s.pdf (accessed on 9 May 2019). 
42. Ibrahim, M.; Sopian, K.; Daud, W.R.W. Study of the drying kinetics of Lemon grass. Am. J. Appl. Sci. 2009, 6, 1070. [CrossRef]

43. Fudholi, A.; Othman, M.Y.; Ruslan, M.H.; Yahya, M.; Zaharim, A.; Sopian, K. Design and Testing of Solar Dryer for Drying Kinetics of Seaweed in Malaysia; University Kebangs Malaysia: Bangi New Town, Selangor, Malaysia, 2011; pp. 119-124.

44. Mitchell, P.H. Calculating the Equilibrium Moisture Content for Wood Based on Humidity Measurements. Bioresources 2018, 13, 171-175. [CrossRef]

45. Shiga, T.M.; Peroni-Okita, F.H.G.; Carpita, N.C.; Lajolo, F.M.; Cordenunsi, B.R. Polysaccharide composition of raw and cooked chayote (Sechium edule Sw.) fruits and tuberous roots. Carbohydr. Polym. 2015, 130, 155-165. [CrossRef]

46. Apati, G.P.; Furlan, S.A.; Laurindo, J.B. Drying and rehydration of Oyster mushroom. Braz. Arch. Biol. Technol. 2010, 53, 945-952. [CrossRef]

47. Brooks, M.S.; Abou El-Hana, N.H.; Ghaly, A.E. Effects of tomato geometries and air temperature on the drying behavior of plum tomato. Am. J. Appl. Sci. 2008, 5, 1369-1375. [CrossRef]

48. Ruiz-López, I.I.; Huerta-Mora, I.R.; Vivar-Vera, M.A.; Martínez-Sánchez, C.E.; Herman-Lara, E. Effect of Osmotic Dehydration on Air-Drying Characteristics of Chayote. Dry. Technol. 2010, 28, 1201-1212. [CrossRef]

49. Imsic, M.; Winkler, S.; Tomkins, B.; Jones, R. Effect of storage and cooking on beta-carotene isomers in carrots (Daucus carota L. cv. 'Stefano'). J. Agric. Food Chem. 2010, 58, 5109-5113. [CrossRef]

(C) 2019 by the authors. Licensee MDPI, Basel, Switzerland. This article is an open access article distributed under the terms and conditions of the Creative Commons Attribution (CC BY) license (http://creativecommons.org/licenses/by/4.0/). 